\title{
ANALYSIS OF TRANSACTION TAX CONTROL BETWEEN RELATED PARTIES IN RUSSIAN FEDERATION
}

\author{
Ajdar M. Tufetulov ${ }^{1}$ \\ Fatih Sh. Nugaev ${ }^{2}$ \\ Andrey S. Zayats ${ }^{3}$
}

\begin{abstract}
Nowadays the system of transaction tax control between interdependent persons in Russian Federation is close to international standards both by the process of transaction tax control between interdependent persons, by used monitoring instruments, and by the mechanism for pricing agreement conclusions.In order to analyze the tax control of transactions between interdependent persons, it is advisable to consider the process of transaction tax control between interdependent persons that has been carried out in Russian Federation since the 2000-ies.The following research methods were used in order to identify the results of transaction tax control analysis among interdependent persons: analysis and synthesis, induction and deduction, comparison methods, economic-
\end{abstract} mathematical and econometric methods.The results of transaction tax control analysis between interdependent persons show that the issues of transaction tax control between interdependent persons became more relevant every year. The authors of the article also found that the number of disputes increased by $1673 \%$, which is undoubtedly the indicator of the largescale growth concerning the relevance of problematic moments in the process of tax control between interdependent persons. The developed analysis and the forecast of the time series with the application of econometric methods allows to draw the conclusion that certain negative tendencies in the process of transaction tax control implementation between interdependent persons will be preserved.The tendencies that have appeared in the area of

\footnotetext{
${ }^{1}$ Kazan Federal University

${ }^{2}$ Kazan Federal University.

${ }^{3}$ Kazan Federal University. E-mail: zayatsas@yandex.ru.Tel.: + 79297226790
} 
transaction tax control between interdependent persons since the 2000ies, exist up to the present time. The forecast of the time series compiled on the basis of actual data confirms that the number of tax disputes will grow after 2013. Therefore, in order to neutralize these trends, further research is needed in terms of transaction tax control causes, problems and risks determination between interdependent persons in Russian Federation.

Keywords: tax control, the transactions between interdependent persons, econometric methods, economicmathematical methods, research.

\section{Introduction}

The purpose of transaction tax control analysis between interdependent persons is to identify trends, as well as quantitative and qualitative criteria for its effectiveness.
In the process of transaction tax control analysis between interdependent persons, certain tendencies can be identified characterizing the system of transaction tax control between interdependent persons [1, p. 107]:

- increased attention of tax authorities to tax control of transactions between interdependent persons;

- an increasing number of tax disputes arising in the process of transaction tax control between interdependent persons;

- a low share of winning cases from a tax authority in the total volume of tax disputes arising in the process of transaction tax control between interdependent persons.

During the period from 2002 to 2013, an upward trend in the number of tax disputes is observed arising in the process of transaction tax control between interdependent persons, which is shown on Figure 1. 


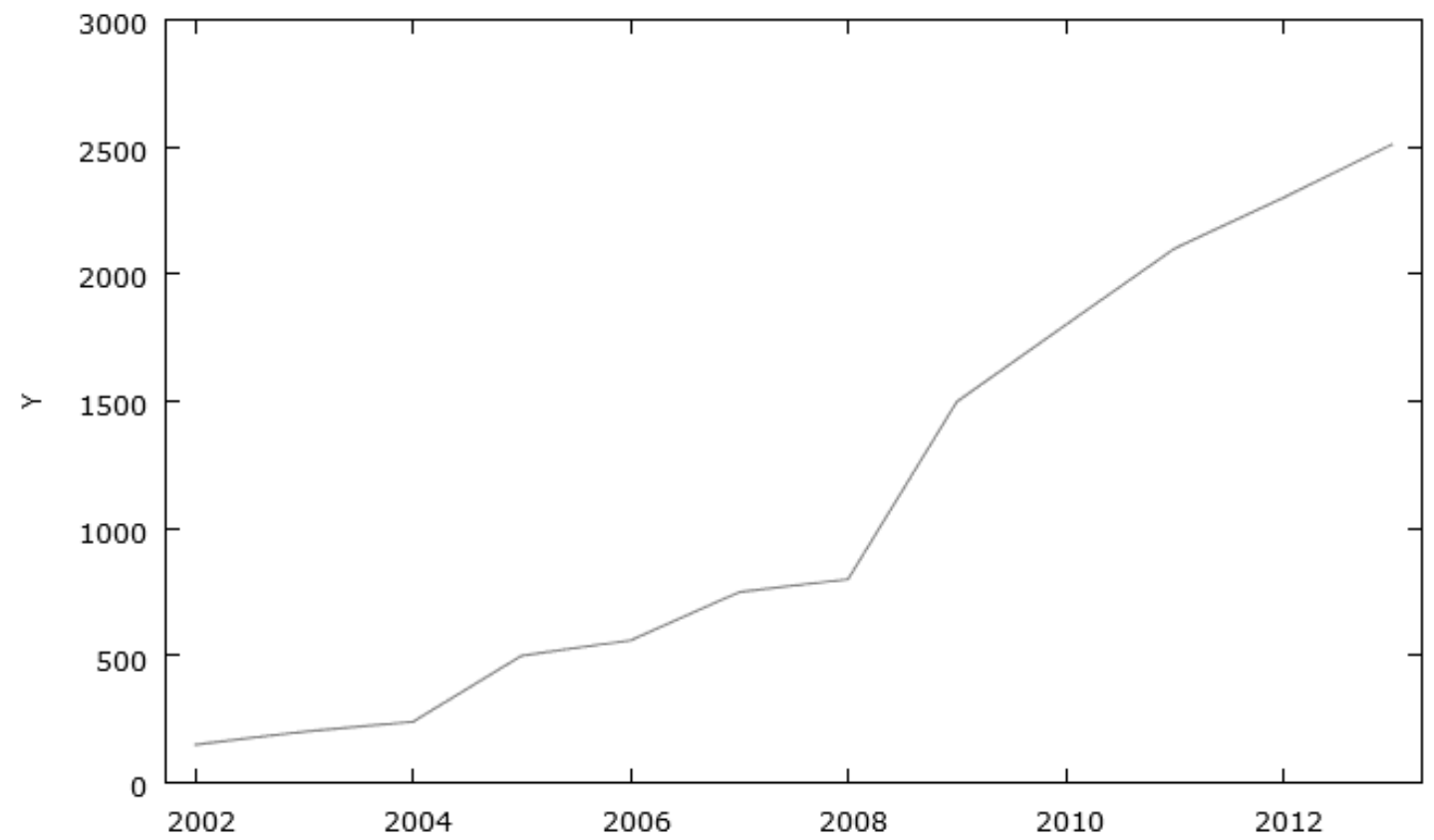

Fig. 1. The dynamics of tax dispute $(\mathrm{Y})$ number that arose in the process of transaction tax control between interdependent persons for the period of 2002-2013.

In order to confirm these trends, tax control between interdependent persons.

the factor analysis of transaction tax control was performed between Methods interdependent persons in Russian Federation during the period of 2000In order to analyze the audit 2013, as well as the economic and mathematical modeling of its implementation trends. The results of the study confirm logically determined tendencies of transaction tax control between interdependent persons, and also suggest a further study in the form of risks and problems identification that arise both for taxpayers and tax authorities in the process of transaction activities of tax authorities for interdependent persons and the development of prices for transactions between them, the information was used on the number of tax disputes, since there are no other effective statistics in the reporting of tax authorities.

In order to analyze the dynamics of tax dispute number, we introduce the concepts of growth rate and absolute growth. The chain growth rate 
shows how many times (by what percentage) the value of an observed period indicator has increased in comparison with the value of the indicator for the previous period [2, p. 5]:

$$
\mathrm{K}_{\text {p.ц. }}=\mathrm{y}_{\mathrm{i}} / \mathrm{y}_{\mathrm{i}-1}
$$

where: $y_{i}$ - the value of the observed period indicator;

$\mathrm{y}_{\mathrm{i}-1}$ - the value of the indicator for the previous period.

At the same time, the basic growth rate shows how many times (by what percentage) the value of an observed period indicator has increased in comparison with the value of the indicator for the basic (initial) period:

$$
\mathrm{K}_{\text {p.б. }}=\mathrm{y}_{\mathrm{i}} / \mathrm{y}_{0} \text {, }
$$

where $y_{i}$ is the value of an observed period indicator;

$\mathrm{y}_{0}$ - the value of the indicator for the basic (initial) period.

The absolute chain increment shows the absolute value by which the indicator increased during the observed period in comparison with the previous period $[2$, p. 6]:

$\mathrm{K}_{\text {аб.прир.ц. }}=\mathrm{y}_{\mathrm{i}}-\mathrm{y}_{\mathrm{i}-1}$, where $y_{i}$ is the value of an observed period indicator;

$\mathrm{y}_{\mathrm{i}-1}$ - the value of a previous period indicator.

An absolute basic increase shows the absolute value by which the indicator increased during the observed period in comparison with the initial one:

$\mathrm{K}_{\text {аб.прир.б. }}=\mathrm{y}_{\mathrm{i}}-\mathrm{y}_{0}$

where $y_{i}$ is the value of an observed period indicator;

$\mathrm{y}_{0}$ - the indicator value for a basic (initial) period.

In order to describe and predict the model of tax dispute number in the course of transaction tax control between interdependent persons for the period of 2002-2013 it is advisable to use econometric methods of time series modeling and forecasting.

Table 2 will be used as the data for the econometric modeling of the time series describing the number of disputes during the tax control of transactions between interdependent persons. All the steps of econometric modeling should be implemented using the Gretl application software, starting with the process of the model parameter formalizing, the 
finding of their estimates, the validation of the model and ending with the prediction of the model data and the development of the time series trend.

Table 2: Initial data for the purposes of econometric modeling

\begin{tabular}{|l|l|l|l|l|l|l|l|l|l|l|l|l|}
\hline Years & 2002 & 2003 & 2004 & 2005 & 2006 & 2007 & 2008 & 2009 & 2010 & 2011 & 2012 & 2013 \\
\hline $\begin{array}{l}\text { Number } \\
\text { of } \\
\text { disputes, } \\
\text { pcs. }\end{array}$ & 150 & 201 & 240 & 500 & 560 & 750 & 800 & 1498 & 1800 & 2100 & 2300 & 2510 \\
\hline
\end{tabular}

For the purposes of time series econometric modeling and prediction, we introduce the following notations:

- Y - the number of tax disputes arising during the tax control of transactions between interdependent persons (dependent factor);

- time - the year of transaction tax control between interdependent persons (independent factor).

When they assess the factors of the model and their effect on a dependent factor (the number of disputes) the method of least squares is used. It consists in sum minimization of the quadratic deviation between the observed and calculated values. The calculated values are found by the selected regression equation. The smaller the difference between the actual values and the calculated ones, the more accurate the forecast based on the regression equation.

The formula of least square method [3, p. 193]:

$$
\mathrm{y}_{\mathrm{t}+1}=\mathrm{a} * \mathrm{X}+\mathrm{b}
$$

where: $\mathrm{t}+1$ - prediction period;

$\mathrm{Yt}+1$ - prediction indicator;

$\mathrm{a}$ and $\mathrm{b}$ - coefficients;

$\mathrm{X}$ - conventional time indicator.

The calculation of $a$ and $b$ coefficients is performed by the following formulas: 


$$
a=\frac{\sum_{i=1}^{n}(y \phi * X)-\left(\sum_{i=1}^{n} X * \sum_{i=1}^{n} y \phi\right) / n}{\sum_{i=1}^{n} X^{\wedge} 2-\left(\sum_{i=1}^{n} X\right)^{\wedge} 2 / n}
$$

(6)

$$
b=\frac{\sum_{i=1}^{n} y \phi}{n}-\frac{a^{*} \sum_{i=1}^{n} X}{n}
$$

\section{(7)}

where: $\mathrm{y}_{\phi}$ are the actual values of dynamics series;

$\mathrm{n}-$ the number of time series levels.

\section{Results}

The obtained model explaining the time trend of tax dispute number arising in the process of transaction tax control between interdependent persons is shown on Figure 2, where the main quality indicators of the obtained model are displayed.

Модель 1: мнк, использованы наблюдения 2002-2013 (Т = 12)

\begin{tabular}{|c|c|c|c|c|}
\hline & КоэФФициент & Ст. ошибка & t-статистика & Р-значениє \\
\hline const & $-410,652$ & 135,431 & $-3,032$ & 0,0126 \\
\hline time & 235,087 & 18,4014 & 12,78 & $1,62 \mathrm{e}-07$ \\
\hline
\end{tabular}

Зависимая переменная: Y

$\begin{array}{lrll}\text { Среднее зав. перемен } & 1117,417 & \text { Ст. откл. зав. перемен } & 873,2002 \\ \text { Сумма кв. остатков } & 484213,8 & \text { Ст. ошибка модели } & 220,0486 \\ \text { R-квадрат } & 0,942268 & \text { Испр. R-квадрат } & 0,936495 \\ \text { F (1, 10) } & 163,2141 & \text { Р-значение (F) } & 1,62 e-07 \\ \text { Лог. правдоподобие } & -80,65951 & \text { Крит. Акаике } & 165,3190 \\ \text { Крит. Шварца } & 166,2888 & \text { Крит. Хеннана-Куинна } & 164,9600 \\ \text { Параметр rhо } & 0,514208 & \text { Стат. Дарбина-Вотсона } & 0,753271\end{array}$

Fig. 2. The model of the time series concerning the number of tax disputes arising in the process of transaction tax control between interdependent persons in 2002-2013. 
The graph of deviations observed from the calculated values is shown in Fig. 3 and demonstrates the degree of a model reliability in terms of calculated value spread degree from the actual ones, which allows to perform a visual analysis of a designed model quality degree.

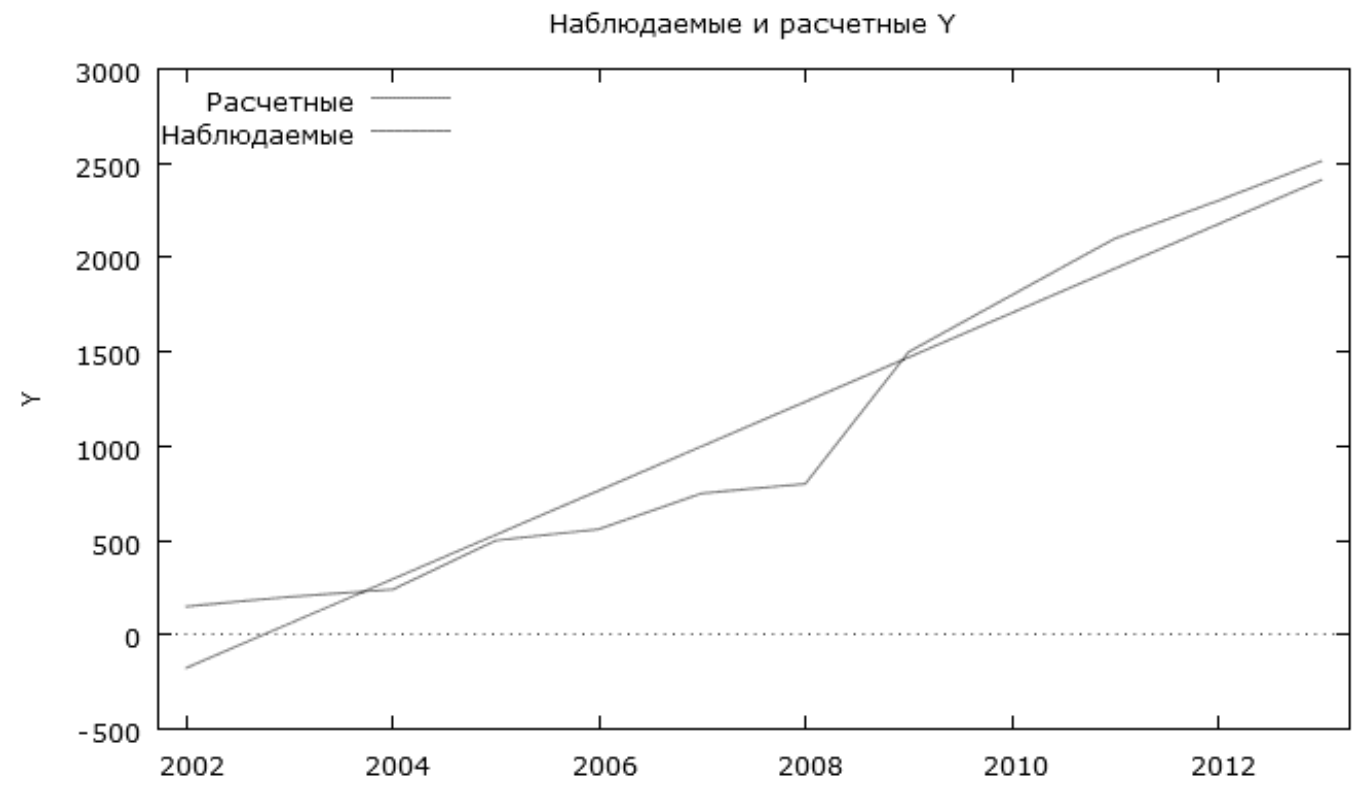

Fig. 3. The graph of observed and calculated values according to the model

The visual analysis of observed and calculated value graph according to the model allows to conclude that the observed values are scattered slightly along the line of predicted values for the model, which allows us to make a preliminary conclusion about the reliability of the constructed model. However, it is necessary to calculate and analyze the main indicators of the model significance as a whole for the final confirmation of this conclusion:

- P-values of the coefficients;
- the determination coefficient $\mathrm{R}^{2}$.

The obtained model of dispute number time series that arose in the process of transaction tax control between interdependent persons during the period of 2002-2013 is the following one:

$$
\mathrm{Y}=-410,652+235,087 * \text { time. }
$$

It is advisable to analyze the reliability of the obtained coefficients by the means of the obtained $\mathrm{P}$ value 
analysis. P-value is the value used in statistical hypothesis testing. In fact, this is the probability of error during the rejection of null hypothesis (the error of the first kind). Hypothesis testing using $\mathrm{P}$-value is the alternative to the classical verification procedure through the critical distribution value.

Usually, P-value is equal to the probability that a random variable with a given distribution (the distribution of test statistics under the null hypothesis) will take a value no less than the actual value of the test statistics.

Let $\mathrm{T}(\mathrm{X})$ is the statistics used in the testing of a certain null hypothesis $\mathrm{H}_{0}$. It is assumed that if the null hypothesis is valid, then the distribution of this statistics is known. Let's denote the distribution function $\mathrm{F}(\mathrm{t})=\mathrm{P}(\mathrm{T}<\mathrm{t})$.

he $\mathrm{P}$-value is determined in the following way most often (during the verification of a right-handed alternative) [3, p. 195]:

$$
\mathrm{P}(\mathrm{t})=\mathrm{P}(\mathrm{T}>\mathrm{t})=1-\mathrm{F}(\mathrm{t})(8)
$$

When a left-hand alternative is checked:

$$
\mathrm{P} 0(\mathrm{t})=\mathrm{P}(\mathrm{T}<\mathrm{t})=\mathrm{F}(\mathrm{t})(9)
$$

In the case of a two-sided test the p-value is:

$$
\mathrm{P}(\mathrm{t})=2 * \min \left(\mathrm{P}_{0}, \mathrm{P}\right)(10)
$$

If $p(t)$ is less than a given level of significance, then the null hypothesis is rejected in favor of the alternative one. Otherwise, it is not rejected.

If the P-value is less than 0.05 , then the coefficient is significant at the level of 0.05 . If P-value is less than 0.01, then the coefficient is significant at the level of 0.01 .

The $\mathrm{P}$ values obtained from the model results were the following ones:

- $\mathrm{P}_{\text {const }}=0.0126$;

- $\mathrm{P}_{\text {time }}=0$.

All the obtained P-values are significant by factors, which is one of the main indicators of the model significance as a whole. At the same time, it is necessary to verify the significance of the model by determination coefficient.

The coefficient of determination $\left(\mathrm{R}^{2}\right)$ is the fraction of the dependent variable dispersion, explained by the model under consideration. In the case of a linear relationship, $\mathrm{R}^{2}$ is the square of the so-called multiple correlation coefficient between the dependent variable and the explanatory variables. In particular, the 
determination coefficient is equal to the square of the usual correlation coefficient between $\mathrm{y}$ and $\mathrm{x}$ for the linear regression model with one characteristic $\mathrm{X}$.

The true coefficient of the dependence model determination of the random variable y on the characteristics $\mathrm{x}$ is determined as follows [4, p. 31]:

$$
R^{2}=1-\frac{V(y \mid x)}{V(y)}=1-\frac{\sigma^{2}}{\sigma_{y}^{2}},
$$

where: $V(y \mid x)=\sigma^{2} \quad$ - conditional (according to $\mathrm{x}$ features) variance of the dependent variable (the variance of a model random error).

In this definition, they use true parameters characterizing the distribution of random variables. If they use a selective estimation of the corresponding variance values, we obtain the formula for the selective determination coefficient (which is usually implied as the coefficient of determination) [4, p. 32]:

$R^{2}=1-\frac{\widehat{\sigma}^{2}}{\widehat{\sigma}_{y}^{2}}=1-\frac{E S S / n}{T S S / n}=1-\frac{E S S}{T S S}$, where:

$$
E S S=\sum_{t=1}^{n} e_{t}^{2}=\sum_{t=1}^{n}\left(y_{t}-\widehat{y}_{t}\right)^{2}
$$

the sum of regression residual squares;

$$
T S S=\sum_{t=1}^{n}\left(y_{t}-v\right)^{2}=n \partial_{y}^{2}
$$

common dispersion; $y_{t}, \bar{y}_{t}$ - the actual and the calculated values of the explained variable respectively;

$$
\bar{y}=\frac{1}{n} \sum_{i=1}^{n} y_{i} \text { - selective average. }
$$

The determination coefficient takes the values from 0 to 1 . The closer the value of the coefficient to 1 , the stronger the dependence. During the evaluation of regression models this is interpreted as the model correspondence to the data. It is assumed for acceptable models that the determination coefficient should be $50 \%$ at least (in this case the coefficient of multiple correlation exceeds $70 \%$ by module). The models with the determination coefficient above $80 \%$ can be considered quite good (the correlation coefficient exceeds 90\%). The equality of the determination coefficient to unity means that the explained variable is described by the model under consideration exactly. 
In the resulting model, $\mathrm{R}^{2}$ was

0.9423. The interpretation of this indicator means that the model is quite adequate. It is reliable by $94.23 \%$, that is, $94.23 \%$ of the transactions between interdependent transaction persons arising in the process of tax control are explained by the developed model, and $5.77 \%$ of the disputes are explained the action of random factors not included in the model.

In other words, the accuracy of regression equation selection is high.

\section{Discussion}

The developed time series of tax dispute number arising in the tax control process of transactions between interdependent persons allows us to forecast the trend of a time series development, that is, to determine the magnitude of tax disputes for 2014 and subsequent years.

The extrapolation method used in the forecasting does not give exact results for a long period of the forecast, because this method is based on the past and the present, and thus the error accumulates. This method gives positive results for the near future of certain object forecasting (no more than 5 years).

The simplest method of extrapolation in general form can be represented as the determination of the function value $[5$, p. 35]:

$$
\hat{\mathrm{Y}}_{t+l}=f\left(y_{t l}\right)(13)
$$

where: $\hat{\mathrm{Y}}^{t+l_{-}}$- extrapolated level value;

$\mathrm{L}$ - the period of anticipation;

$\mathrm{V}_{\mathrm{t}}$ - the level taken as the extrapolation base.

The extrapolation on the basis of average time series value is based on the assumption that the average level of the series does not tend to change or if this change is insignificant, one can assume that $\hat{\mathrm{Y}}_{t+l}=\overline{\mathrm{V}}$ i.e. the predicted level is equal to the average value of the levels in the past.

Confidence limits for an average with a small number of observations are defined as follows [5, p. 36]:

$$
\hat{y}_{t+l}=\overline{\mathrm{V}} \pm t_{2} S_{\bar{y}}(14)
$$

where: $t_{a}-$ the table value $t$ of Student's statistics with n-1 degrees and the probability level p;

$S_{y}$ is the mean square error of the mean value. 
The value of the mean square error is determined by the formula. In its turn, the mean square deviation for the sampling makes $[5$, p. 36]:

$$
S=\sqrt{\frac{\sum_{t=1}^{n}\left(y_{t}-\bar{y}\right)^{2}}{n-1}}
$$

where $y_{t}$ is the actual value of the indicator.

The total variance, related both to the variability of a mean sample, and to the variation of individual values around the mean, will amount to $S^{2}+S^{2} / n$. Thus, the confidence intervals for the prognostic evaluation are the following ones:

$$
\bar{Y}_{t+l}=\bar{Y} \pm t_{a s} S \sqrt{1+\frac{1}{n}}
$$

\section{CONCLUSIONS}

Table 1 summarizes the analysis results concerning the number of disputes that arose during the tax control of transactions between interdependent persons in Russian Federation for the period of 2000-2013.

Table 1

The analysis of tax dispute number in the course of transaction tax control between interdependent persons

\begin{tabular}{|c|c|c|c|c|c|c|c|c|c|c|c|c|c|}
\hline Colum & Years & $\begin{array}{l}200 \\
2\end{array}$ & $\begin{array}{l}200 \\
3\end{array}$ & 2004 & $\begin{array}{l}200 \\
5\end{array}$ & $\begin{array}{l}200 \\
6\end{array}$ & $\begin{array}{l}200 \\
7\end{array}$ & $\begin{array}{l}200 \\
8\end{array}$ & $\begin{array}{l}200 \\
9\end{array}$ & $\begin{array}{l}201 \\
0\end{array}$ & $\begin{array}{l}201 \\
1\end{array}$ & $\begin{array}{l}201 \\
2\end{array}$ & $\begin{array}{l}201 \\
3\end{array}$ \\
\hline 1 & $\begin{array}{l}\text { Number } \\
\text { of } \\
\text { disputes, } \\
\text { pcs. }\end{array}$ & 150 & 201 & 240 & 500 & 560 & 750 & 800 & $\begin{array}{l}1 \\
498\end{array}$ & $\begin{array}{l}1 \\
800\end{array}$ & $\begin{array}{l}2 \\
100\end{array}$ & $\begin{array}{l}2 \\
300\end{array}$ & $\begin{array}{l}2 \\
510\end{array}$ \\
\hline 2 & $\begin{array}{l}\text { Coeffici } \\
\text { ent of } \\
\text { growth } \\
\text { (chain) }\end{array}$ & - & 1,34 & $\begin{array}{l}1,1 \\
9\end{array}$ & $\begin{array}{l}2,0 \\
8\end{array}$ & $\begin{array}{l}1,1 \\
2\end{array}$ & $\begin{array}{l}1,3 \\
4\end{array}$ & $\begin{array}{l}1,0 \\
7\end{array}$ & $\begin{array}{l}1,8 \\
7\end{array}$ & 1,2 & $\begin{array}{l}1,1 \\
7\end{array}$ & $\begin{array}{l}1,0 \\
9\end{array}$ & $\begin{array}{l}1,0 \\
9\end{array}$ \\
\hline 3 & $\begin{array}{l}\text { Average } \\
\text { coefficie }\end{array}$ & 1,32 & & & & & & & & & & & \\
\hline
\end{tabular}
from 2002 to 2013. 


\begin{tabular}{|c|c|c|c|c|c|c|c|c|c|c|c|c|c|}
\hline & $\begin{array}{l}\text { nt of } \\
\text { growth } \\
\text { (col. } \\
2 / 11)\end{array}$ & & & & & & & & & & & & \\
\hline 4 & $\begin{array}{l}\text { The } \\
\text { growth } \\
\text { rate } \\
\text { (basic) }\end{array}$ & 16 & & & & & & & & & & & \\
\hline 5 & $\begin{array}{l}\text { Absolute } \\
\text { growth } \\
\text { (chain), } \\
\text { pcs. }\end{array}$ & - & 51 & 39 & $\begin{array}{l}26 \\
0\end{array}$ & 60 & $\begin{array}{l}19 \\
0\end{array}$ & 50 & $\begin{array}{l}69 \\
8\end{array}$ & $\begin{array}{l}30 \\
2\end{array}$ & $\begin{array}{l}30 \\
0\end{array}$ & $\begin{array}{l}20 \\
0\end{array}$ & $\begin{array}{l}21 \\
0\end{array}$ \\
\hline 6 & $\begin{array}{l}\text { Absolute } \\
\text { increase } \\
\text { on } \\
\text { average, } \\
\text { pcs. (col. } \\
5 / 11 \text { ) }\end{array}$ & \multicolumn{12}{|c|}{214} \\
\hline 7 & $\begin{array}{l}\text { Absolute } \\
\text { increase } \\
\text { (basic), } \\
\text { pcs. }\end{array}$ & \multicolumn{12}{|c|}{2360} \\
\hline
\end{tabular}

The analysis of tax dispute number in the course of transaction tax control between interdependent persons shows that during the period of 20022013 the number of disputes increased by 214 (32\%) every year on the average, according to the data of Table 2.1.1. In relation to 2002, the number of disputes increased significantly by 2,360
(1673\%) disputes in 2013. Such a significant absolute increase in the number of disputes also confirms the growing relevance of transaction tax control problems between interdependent persons.

The prediction of the time series levels using the Gretl application program showed that the number of tax 
disputes in 2014, 2015 and 2016, will be 2645, 2880 and 3115 cases, respectively (Figure 4) with $95 \%$ probability, that is, the upward trend in the number of disputes that have arisen in the process of transaction tax control between interdependent persons will be preserved (Figure 5).

Для 95\% доверительных интервалов, $t(10,0,025)=2,228$

Y Предсказание Ст. ошибка 95\% доверительный интервал

$\begin{array}{lllll}2009 & 1498,00 & 1470,05 & & \\ 2010 & 1800,00 & 1705,14 & & \\ 2011 & 2100,00 & 1940,22 & & \\ 2012 & 2300,00 & 2175,31 & & \\ 2013 & 2510,00 & 2410,40 & & \\ 2014 & & 2645,48 & 135,431 & 2343,73-2947,24 \\ 2015 & & 2880,57 & 151,928 & 2542,06-3219,09 \\ 2016 & & 3115,66 & 168,819 & 2739,51-3491,81\end{array}$

Fig. 4. The results of time series level prediction using the Gretl application program

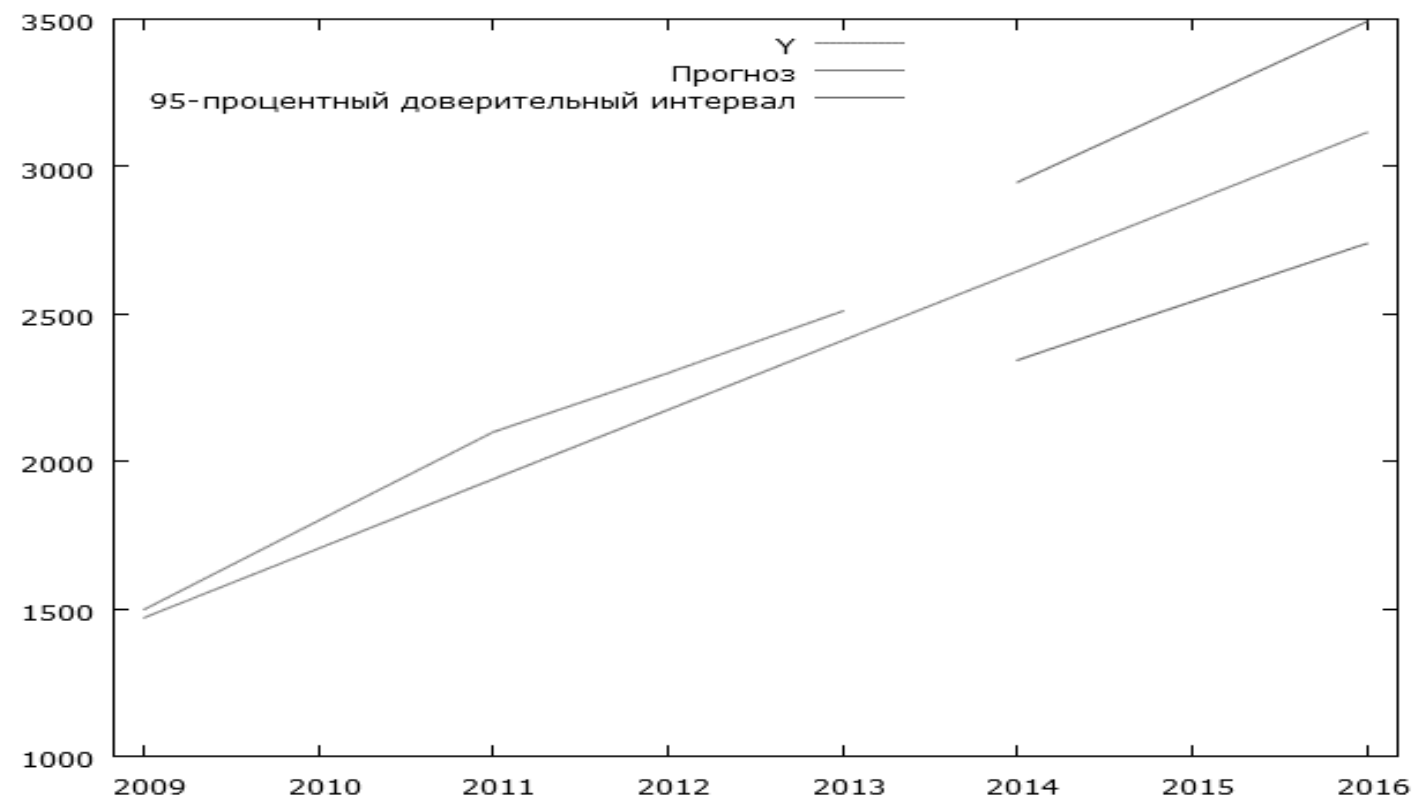

Fig. 5. Graphical forecast of the trend line in terms of the number of disputes arising in the process of transaction tax control between interdependent persons

The designed analysis and the forecast of the time series allows us to conclude that certain negative trends in the process of transaction tax control between interdependent persons will continue. 


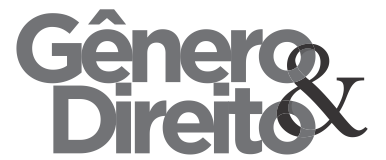

Summary

Thus, the trends that have arisen in the part of transaction tax control between interdependent persons since the 2000s, exist up to the present time, the forecast of the time series compiled on the basis of actual data confirms that the number of tax disputes will grow after 2013. Therefore, in order to level these trends, it is expedient to begin, first of all, with the definition of the causes and the problems of transaction tax control between interdependent persons in Russian Federation.

\section{Acknowledgements}

The work is performed according to the Russian Government Program of Competitive Growth of Kazan Federal University.

\section{References}

Grundel L.P. Analysis of tax control practice concerning the application of transfer pricing in Russia / L.P. Grundel // Taxes and financial law. - 2014. - No. 11. pp. 106-111.
Periódico do Núcleo de Estudos e Pesquisas sobre Gênero e Direito

Centro de Ciências Jurídicas - Universidade Federal da Paraíba V. 8 - No 04 - Ano 2019 - Special Edition ISSN | 2179-7137 | http://periodicos.ufpb.br/ojs2/index.php/ged/index

Wolvach D.W. The practice of new rules application concerning the tax control of prices in the transactions between interdependent persons in Russia / D.V. Wolvach // Economics. Taxes. Law: The collection of scientific articles from financial University. - Moscow, 2014. No. 1. - pp. 4-9.

Maruschak D.V. The analysis of transfer pricing and its application in international practice / D.V. Marushchak // Financial and credit system. Budget, currency and credit regulation of economy. - 2014. - No. 3. - pp. 192-196.

Polisyuk G.B. The analysis of transfer pricing influence on the activity of an enterprise and its taxation in international practice [Text] / G.B. Polisyuk, I.V. Ilyashik // International accounting. - 2010. - No. 6. - pp. 29-36.

Polisyuk G.B. The analysis of state regulation for transfer pricing: the ways of international and Russian legislation development / G.B. Polisyuk // International accounting. - 2010. - No. 9. pp. 32-38.

On the amending of certain legislative acts of Russian Federation concerning the 
improvement of price determination

principles for tax purposes: Federal Law

No. 227-FL issued on July 18, 2011 //

Russian journal. - 2011. No. 5535.

Kirpikov A.N. Relevant approaches to performing analysis of financial results of organization's activity with application of factor models / A.N. Kirpikov, F.S. Nugaev // International Business Management. - Volume 10. - Issue 15. 2016. - Pages 2987-2991.

Tufetulov A.M. Transaction tax control algorithm between related persons A.M. Tufetulov, F.S. Nugaev, A.S. Zayats // International Business Management. Volume 9. - Issue 7. - 2015. - Pages 17851791.

Fiebig, $\quad$ D.G. (2007).

Microeconometrics: Methods and Applications by A. Colin Cameron \& Pravin K. Trivedi. Economic Record 83, 112-113.

Wooldridge, J.M. (2007). Econometric

Analysis of Cross Section and Panel

Data, 2nd edition. New York: John

Wiley \& Sons. 